\title{
RELIGIOUS TOURISM IN GEORGIA
}

Larisa Korganashvili ${ }^{1}$

${ }^{1}$ Ivane Javakhishvili Tbilisi State University, Tbilisi, Georgia
Correspondence:

Larisa Korganashvili

e-mail:

I.korganashvili@yahoo.com

\begin{abstract}
:
Georgia is the country of the most ancient civilization and centuries-old Christian history. It has a rich religious, historical and cultural heritage, which can contribute to creating various tourism products and increasing the country's attractiveness. This paper outlines the potential of religious tourism in Georgia and identifies problems and opportunities for its development.
\end{abstract}

\section{Keywords:}

tourism, religion, Christianity, cultural heritage, Georgia.

\section{INTRODUCTION}

Religions occupy a special place in peoples' lives and in every society, as the necessary element of all cultures. Orthodox Christianity represents the basis of the identity and the independence of Georgian people. The religious component takes a special place in the cultural heritage of Georgia. Religions had a significant impact on the world view of peoples for many millennia. They determined their social behaviour, shaped the nature of economic relations, political structures of states, relations among people, etc. Despite this, most economists ignored, until recently, the religious factor in their analyses of economic processes. However, at present, the religion is regarded as an independent factor of economic development. Travels with the purpose of visiting holy places have always been particularly important religious activity of people since ancient times, although the motives for travelling to holy places differ. It can be an act of faith, desire to solve personal problems, wish to get acquainted with the cultural heritage of the country, etc. In the post-Soviet Georgia, the people have the opportunity to visit holy places freely and to satisfy their spiritual needs. In this regard, the religious paradigm gave impetus to the development of religious tourism, and tourism in general. Hundreds of tourists make pilgrimages to holy places every year. However, given the number of holy places in Georgia, international tourist arrivals for religious purposes can be much higher, especially since religious tourism is one of the most dynamically developing and promising areas of the modern tourism industry. The purpose of this paper is to study the possibilities for the development of religious tourism in Georgia and its contribution to the economy of the country. 


\section{RESULTS AND DISCUSSION}

The transition of Georgia from a socialist system to a market economy is characterized by many features, among which is the strengthening of the population's religiosity. In the Soviet atheistic society, people had suppressed their faith, but in the sovereign Georgia, believers gained the freedom of religion and began visiting holy places and religious monuments. Religion deeply penetrates the spiritual life of people and it expands opportunities for tourist exchanges. At the present time, religious cultural monuments are becoming tourist sites and conditions for the development of religious tourism are improving. Revenues derived from religious tourism will contribute to the economic development of the country. Religious values represent a component of the national identity. The connection between the religiosity of the population and other forms of public consciousness (moral, legal, economic, etc.) and economic growth has been studied by many scientists.

E. Durkheim considers religion as the basis of social integration, the birth of culture and the values transfer from generation to generation. Its main social function is the awakening of human solidarity and the promotion of ideals, values and norms that stimulate social development. In his opinion, the society is the "body"', self-regulated and subject to social diseases, the state is the "mind", and the religion is the "collective soul" of the organism (Durkheim, 1912/1954).

M. Weber studied the influence of religion and its ethical norms on economic aspects of a society in its specific historical and geographical manifestations and concluded that the religion is important for its economic success (Weber, 1930).

Robert Barro, and other scientists, conducted a series of studies on the relationship between the religiosity of the population and the economic growth of different countries. His main conclusion was that believing in God can increase economic growth (Barro, 2003).

According to David Landes, differences in levels of economic development in almost all countries can be explained by their cultures (Landes, 1998). Many researchers also believe that the religion is a necessary element of the culture, fulfilling important social functions.

The basis of the identity for Georgian people is their cultural heritage, which is the most important resource of the country's economic and social development. The religious component takes a special place in Georgian culture. Georgia is an Orthodox country that adopted Christianity as its main religion in the year $326 \mathrm{AD}$. According to the legend, the Mother of God had to go to Georgia to spread, with the apostolic sermon, the doctrine of Christ in new lands. Therefore, Georgia is considered the country chosen by the Mother of God, who is the patroness of the country. However, at the Saviour's will, the Virgin Mary was left in Jerusalem. Instead of her, St. Apostle Andrew the First-Called went there. St. Apostle took with him the Vernicle Image of the Mother of God and visited many cities and villages of Georgia with the Gospel sermon. In the city of Atskuri (near the modern Georgian city of Akhaltsikhe), the Apostle's prayer brought a dead man back to life and this miracle induced the townsmen to accept the Holy Christening. The Apostle left the icon of the Virgin Mary in the city (Religion in Georgia).

The church tradition of Georgia regards Andrew the First-Called as the first preacher of Christianity on the territory of Georgia and the founder of the Georgian church. "Andrew preached to the Iberians, Sauromatians, Taurians, and Scythians and to every region and city, on the Black Sea, both north and south" (Peterson, 1958).

In Western Georgia, together with the Apostle Andrew, the doctrine of Christ was preached by the Apostle Simon Kananit, who is buried there in the village of Komany. Another apostle, St. Matthias, preached in the southwest of Georgia and was buried in Gonio, near the modern Batumi. The most ancient Georgian sources indicate the stay of the apostles Bartholomew and Thaddeus in Eastern Georgia (Kratkayaistoriya).

Christianity in Georgia was subject to persecutions during its first centuries. However, in the year $326 \mathrm{AD}$, Christianity became the established religion in ancient Georgia, thanks to the sermon of St. Nina (She was buried in Bodbe near the Georgian town of Sighnaghi). By the disposition of the Virgin Mary, St. Nina came to Georgia and established the belief in Jesus Christ and initiated building of many temples in memory of the great martyr George the Victory-Bearer. Georgia chose St. George as its heavenly patron. The most ancient relic of Georgia is the shroud of God, which is kept in the Mtskheta cathedral. This place is and always will be the centre of spiritual life of Georgian nation. The Cathedral honouring the 12 Holy Apostles is located there (Religion in Georgia). In addition, Tbilisi Sioni Cathedral holds one of the main shrines of Georgia - the grapevine cross/the Cross of Nina (or Nino, as she is called in Georgia).

Christianity was firmly established in Georgia in the 4th century. Georgia always protected the Orthodox doctrine from external enemies-conquerors: Persians and Arabs, Seljuk Turks, Mongols, Ottomans who tried 
forcefully to spread their religion in the country. Many people took martyr deaths for their belief in Jesus Christ. The world history does not know such an example of self-sacrifice when 100,000 people simultaneously accepted the martyr wreath. The citizens of Tbilisi refused to obey Khoresm-shah Jalaladdin, who ordered them to defile the icons put on the bridge. Men, children and old men were executed. It happened in the year $1226 \mathrm{AD}$. In the year $1386 \mathrm{AD}$, the hordes of Tamerlane annihilated the nuns of the Kvabtakhi covenant. In the year 1616, during the invasion of Shah Abbas, 6,000 monks of David-Garedz monastery accepted martyrdom (Religion in Georgia, Kratkaya istoriya).

Georgia, as the country of the oldest civilization and centuries-old Christian history, has a unique cultural heritage. There are more than 10 thousand monuments of archaeology, history, architecture and art, $150 \mathrm{mu}-$ seums, many cathedrals, monasteries, churches dated back to V-VI centuries and other historical monuments. There are more than 350 temples and churches of St. George - one of the most revered Christian Saints in the country. Christian churches in Georgia are not only treasures of the Orthodox culture of Georgia, but also treasures of the world significance. Historical monuments of Mtskheta - Jvari Temple (586-604), Svetitskhoveli Cathedral (1010-1029), Bagrat Temple (1003) and Gelati Monastery (XII century) in Kutaisi are listed as the World Heritage sites (UNESCO). The preliminary list of the UNESCO World Heritage sites includes Alaverdi Cathedral, Ananuri, David Gareji Monasteries and Hermitage, Dmanisi Hominid Archaeological Site, Gremi Church of Archangels and Royal Tower, Kvetera Church, Nicortsminda Cathedral, Samtavisi Cathedral, Shatili, Tbilisi Historic District, Uplistsikhe Cave Town, and others (UNESCO).
Many monasteries and churches have become educational centres of theology. In the XII century, the great Georgian King David IV founded the Gelati Monastery (near Kutaisi) and its Academy, which has been recognized as the greatest theological and scientific school in the Orthodox world. A monastery near the village of Ikalto was founded in the VI century, where its founder - venerable Zeno Ikaltiyskiy, exhibited the relics for worshiping purposes. As the Gelati monastery, it had its own academy built in the XII century by David the Builder, and it became one of the cultural centres of Georgia. Famous philosopher Arsene Ikaltoeli taught there. One of his students was a great poet Shota Rustaveli, the author of poem "The knight in the tiger skin" (By decision of UNESCO, 2016 was declared the year of Rustaveli).

Despite the significant historical and cultural potential, Georgia has not yet developed tourism infrastructure and it is not competitive enough. According to the rating of the World Economic Forum in 2017, Georgia is in the 70th place among 136 countries regarding the competitiveness of travel and tourism (Travel \& Tourism Competitiveness Index). In 2015, it rated 71st out of 141 countries (WEF, 2017). As shown in Figure 1, the situation improved in 2017 for such components of the T\&TCI as Business Environment, Safety and Security, Health and Hygiene, Human Resources and Labour Market, ICT Readiness, Prioritization of Travel \& Tourism, Cultural Resources and Business Travel, and worsened for components such as Ground and Port Infrastructure and Tourist Service Infrastructure.

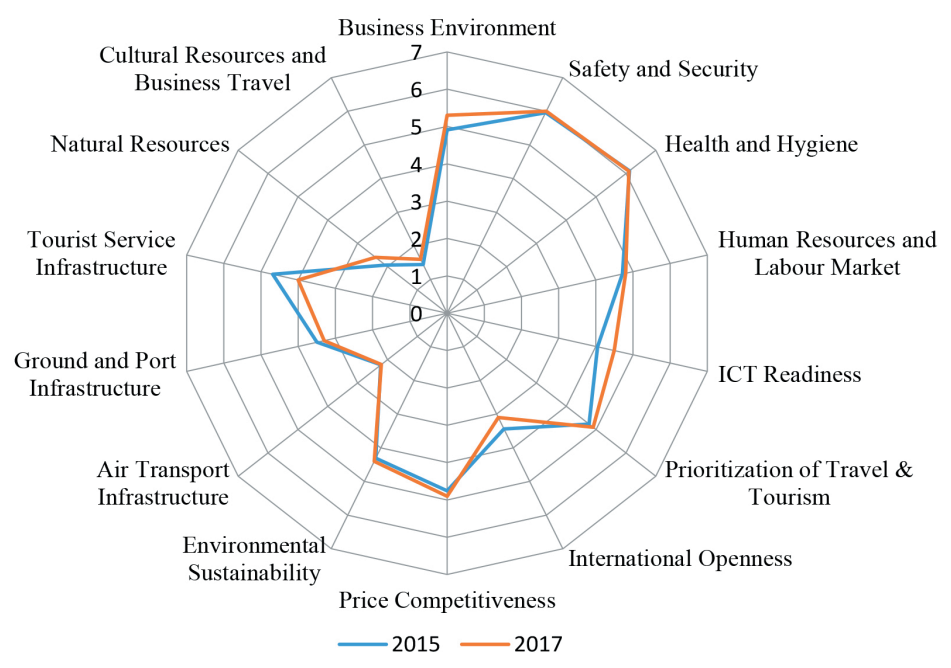

Fig.1. Travel \& Tourism Competitiveness Index of Georgia, 2015 and 2017 
At the same time, the tourism in Georgia demonstrates high growth rates in recent years. 6,350,831 people visited Georgia in 2016, 449,731 more than in the previous year, which represents annual growth of $7.6 \%$. It is also 11 times more visitors than in 2005. The greatest number of visitors came from Azerbaijan (1,523,075, an increase of 9.3\%), followed by Armenia (1,496,246, an increase of 1.9\%) and Turkey (1,254,089 - a decrease of $9.9 \%$ from last year). 1,037,564 Russian visitors visited Georgia in 2016, which is $12 \%$ more than in 2015, while visits from Ukraine increased by $21.8 \%$, amounting to 172,631 people. The year-on-year statistics for visitors from Europe also shows positive signs. The total number of travellers from Lithuania, Latvia, Czech Republic, Bulgaria and Germany has significantly increased as well. An exceptional increase in arrivals was observed from the following countries: Iran (+485\%), India (+ $199 \%)$, Saudi Arabia (+116\%), the Philippines (+ 89\%), Oman (+ $75 \%)$, and China (+46\%). Georgians took a total of 12.96 million domestic trips in 2016, representing $5 \%$ increase over the same period last year (GNTA). The direct contribution of tourism to the country's GDP was GEL 2,721.9 million or USD 1,158.2 million (8.1\%), and the indirect contribution was GEL 9,098.8 million or USD 3,871.8 million (27.1\%). Travel \& Tourism directly supported 122,000 jobs ( $6.8 \%$ of total employment), and the total contribution to employment, including jobs indirectly supported by the industry, was $23.4 \%$ of total employment (420,500 jobs). Visitor exports generated GEL 5,522.2 million (USD 2,349.9 million), 40.8\% of total exports in 2016 (WTTC).

According to the research of the Georgian National Tourism Administration, the number of visitors for religious purposes does not exceed $2 \%$ of the total number of visitors. However, it should be borne in mind that religious tourism is often combined with other types of tourism and it is difficult to isolate from other motives. UNWTO experts evaluate religious tourism as one of the most promising areas of tourism in the 21st century. This can be explained by the fact that it is aimed not only at meeting human needs, but also at developing their spirituality and culture. Tourism helps people learn about different cultural values, build the relationship of trust between representatives of different cultures and religions, solve social and economic problems, form attitudes on cultural values, and their own opinion on the global world. In the context of globalization, tourism serves as an important mechanism for managing intercultural relations of peoples and facilitating development of contacts between different faiths.

Religious tourism is facing increasing demand throughout the world. Monuments of religion, history and culture represent a significant motivation for visiting a particular region or city. The practice shows that religion and tourism use the same cultural heritage and, as a result of their close relationship, it is possible to expand tourist routes. Travellers can be offered a variety of tours associated with a single historical site or period, or the history of particular saints (for example, in the footsteps of St. Andrew or St. Nina, etc.) These routes can be combined with other types of tourism (for example, rest on the Black Sea coast or in the mountains, visit folklore festivals, etc.)

Religious tourism has its own varieties: pilgrimages and cognitive tours of religious orientation. The pilgrimage involves participation in religious cults (pilgrims usually profess the religion which they came to worship at holy places), and cognitive tours of a religious orientation usually involve visits to monasteries, temples, museums, exhibitions, etc. Moreover, religious tourists may or may not be adherents to the religion whose objects are visited, and they can also be unbelievers. According to the research of the International Institute of Tourism Sciences, $53.68 \%$ of travellers participate in divine services, but more than one-third (35.1\%) shows interest in in-depth knowledge of the territory, its nature and resources (MTA, 2010).

It should be noted that the unique religious, historical and cultural heritage of Georgia is not just an element of the tourist offer, but one of the main aspects for tourism development in the country. This heritage can contribute to the formation of various tourism products and increase the country's attractiveness. Considering the fact that an active growth of tourists' interest for local and national religious sites of non-traditional tourist destinations has been observed, Georgia has good chances for successful tourism development. However, the state policy is required to increase interest for Georgia, especially in Orthodox countries among which there are great links of spiritual cultures, and the churches are in Eucharistic communion: many Saints revered in Georgia are known in all Orthodox countries. At the same time, it is necessary to increase popularity and visibility of the tourist brand "Georgia", improve the quality of tourism products, promote Georgian tourism on the world market, use effective marketing strategies and modern information technologies, increase the level of trainings, etc. As a result of all these, tourism, including religious tourism, can become the country's largest source of income and make a significant contribution to the economic development of Georgia. 


\section{CONCLUSION}

Tourism in Georgia is developing at a rapid pace, but it occupies a modest place in the global tourism services market, especially in the religious tourism segment. Georgia has a lot of potential for religious tourism development, which has not been realized yet. Due to the fact that religion and tourism use the same cultural heritage, it is necessary to ensure their close cooperation and integrated approach to tourism and culture.

\section{REFERENCES}

Barro, R. J., McCleary, R. M. (2003). Religion and Economic Growth. NBER Working Paper No. 9682. Retrieved 20 April 2017 from http://www.nber.org /papers/w9682.

Durkheim, E. (1912/1954). The Elementary Forms of Religious Life. (J. Swain, Trans.). New York: The Free Press.

GNTA-Georgian National Tourism Administration . Retrieved 20 April 2017 from http://gnta.ge/statistics/.

Landes, D. S. (1998). The Wealth and Poverty of Nations: Why Some Are So Rich and Some So Poor. W. W. Norton \& Company, Inc.: New York- London. Retrieved 25 April 2017 from https://tsu.ge/data/file $\mathrm{db} /$ faculty_humani- ties/Landes\%20-\%20The\%20 Wealth\%20and\% 20the\%20Poverty\%20of\%20Nations.pdf
Megill Peterson, P. (1958). Andrew, Brother of Simon Peter: His History and Legends. Brill Archive.

Religion in Georgia. Retrieved 20 April 2017 from http:// www.advantour.com/georgia/ religion.htm.

UNESCO. Properties inscribed on the World Heritage List. Retrieved 25 April 2017 from http://whc.unesco.org/en/statesparties/ge.

Weber, M. (1930). The Protestant Ethic and the Spirit of Capitalism. (T. Parsons and A. Giddens, Trans.). London and New York: Unwin Hyman. Retrieved 18 April 2017 from https://www.ttu.ee/public/m/ mart-murdvee/ EconPsy/1/Weber_Max_1930-20 05_The_Protes- tant_Ethic_and_the_Spirit_of_ Capitalism.pdf.

WEF - World Economic Forum. The Travel \& Tourism Competitiveness Report 2017. Paving the way for a more sustainable and inclusive future. Retrieved 17 April 2017 from http://www3. weforum.org/docs/ WEF_TTCR_2017_web_0401. Pdf.

WTTC.Travel \& tourism economic impact 2017, Georgia. Retrieved 20 April 2017 from https://www. wttc.org/-/media/files/reports/ economic-impactresearch/countries-2017/geor- gia2017.pdf.

Краткая история Грузинской Православной Церкви. Retrieved 19 April 2017 from http://www. georgiaorthodoxy.info/index. php?cat=_history.

MTA-Международная туристская академия. (2010). Современное состояние религиозного туризма и его социальная роль в России и за рубежом (аналитический обзор). Москва: 2010. Retrieved 20 April 2017 from http:// www.travelglossary.ru/ knowledge/files/sovremen- noe_sos.doc. 